\title{
North American Influence on Tropospheric Ozone and the Effects of Recent Emission Reductions: Constraints from ICARTT Observations
}

\section{Citation}

Hudman, R.C., Lee T. Murray, Daniel J. Jacob, S. Turquety, S. Wu, D. B. Millet, M. Avery, A. H. Goldstein, J. Holloway. 2009. North American influence on tropospheric ozone and the effects of recent emission reductions: Constraints from ICARTT observations. Journal Geophysical Research 114(D07302): 1-9.

\section{Published Version}

doi:10.1029/2008JD010126

\section{Permanent link}

http://nrs.harvard.edu/urn-3:HUL.InstRepos:3553960

\section{Terms of Use}

This article was downloaded from Harvard University's DASH repository, and is made available under the terms and conditions applicable to Other Posted Material, as set forth at http:// nrs.harvard.edu/urn-3:HUL.InstRepos:dash.current.terms-of-use\#LAA

\section{Share Your Story}

The Harvard community has made this article openly available.

Please share how this access benefits you. Submit a story.

Accessibility 


\title{
North American influence on tropospheric ozone and the effects of recent emission reductions: Constraints from ICARTT observations
}

\author{
R. C. Hudman, ${ }^{1,2}$ L. T. Murray, ${ }^{1}$ D. J. Jacob, ${ }^{1}$ S. Turquety, ${ }^{1,3}$ S. Wu, ${ }^{1}$ D. B. Millet, ${ }^{1,4}$ \\ M. Avery, ${ }^{5}$ A. H. Goldstein, ${ }^{6}$ and J. Holloway ${ }^{7,8}$ \\ Received 14 March 2008; revised 30 December 2008; accepted 21 January 2009; published 4 April 2009.
}

[1] We use observations from the International Consortium for Atmospheric Research on Transport and Transformation (ICARTT) campaign over eastern North America in summer 2004, interpreted with a global 3-D model of tropospheric chemistry (GEOSChem), to improve and update estimates of North American influence on global tropospheric ozone and the effect of recent U.S. anthropogenic reductions on surface ozone pollution. We find that the $50 \%$ decrease in U.S. stationary $\mathrm{NO}_{\mathrm{x}}$ sources since 1999 has decreased mean U.S. boundary layer ozone concentrations by $6-8 \mathrm{ppbv}$ in the southeast and 4-6 ppbv in the Midwest. The observed $d \mathrm{O}_{3} / d \mathrm{CO}$ molar enhancement ratio in the U.S. boundary layer during ICARTT was $0.46 \mathrm{~mol} \mathrm{~mol}^{-1}$, larger than the range of $0.3-0.4$ from studies in the early $1990 \mathrm{~s}$, possibly reflecting the decrease in the $\mathrm{NO}_{\mathrm{x}} / \mathrm{CO}$ emission ratio as well as an increase in the ozone production efficiency per unit $\mathrm{NO}_{\mathrm{x}}$. North American $\mathrm{NO}_{\mathrm{x}}$ emissions during summer 2004 as constrained by the ICARTT observations $(0.72 \mathrm{Tg} \mathrm{N}$ fossil fuel, $0.11 \mathrm{Tg} \mathrm{N}$ biomass burning, $0.28 \mathrm{Tg} \mathrm{N}$ lightning for 1 July to 15 August) enhanced the hemispheric tropospheric ozone burden by $12.4 \%$, with comparable contributions from fossil fuel and lightning (5-6\%), but only $1 \%$ from biomass burning emissions despite 2004 being a record fire year over Alaska and western Canada.

Citation: Hudman, R. C., L. T. Murray, D. J. Jacob, S. Turquety, S. Wu, D. B. Millet, M. Avery, A. H. Goldstein, and J. Holloway (2009), North American influence on tropospheric ozone and the effects of recent emission reductions: Constraints from ICARTT observations, J. Geophys. Res., 114, D07302, doi:10.1029/2008JD010126.

\section{Introduction}

[2] Ozone $\left(\mathrm{O}_{3}\right)$ is produced in the troposphere by photochemical oxidation of methane $\left(\mathrm{CH}_{4}\right)$, carbon monoxide $(\mathrm{CO})$ and nonmethane volatile organic compounds (NMVOCs) in the presence of nitrogen oxides $\left(\mathrm{NO}_{\mathrm{x}}=\right.$ $\mathrm{NO}+\mathrm{NO}_{2}$ ). Anthropogenic emissions of $\mathrm{NO}_{\mathrm{x}}$ and methane have caused a large global increase of tropospheric ozone over the past century [Marenco et al., 1994; Wang and Jacob, 1998] with consequences for the greenhouse effect

\footnotetext{
${ }^{1}$ Department of Earth and Planetary Sciences and School of Engineering and Applied Sciences, Harvard University, Cambridge, Massachusetts, USA.

${ }^{2}$ Now at Department of Chemistry, University of California, Berkeley, California, USA.

${ }^{3}$ Now at Service d'Aéronomie, Institut Pierre-Simon Laplace, Paris, France.

${ }^{4}$ Now at Department of Soil, Water and Climate, University of Minnesota-Twin Cities, St. Paul, Minnesota, USA.

${ }^{5}$ Atmospheric Sciences Division, NASA Langley Research Center, Hampton, Virginia, USA.

${ }^{6}$ Department of Environmental Science, Policy, and Management, University of California, Berkeley, California, USA.

${ }^{7}$ Cooperative Institute for Research In Environmental Science, University of Colorado, Boulder, Colorado, USA.

${ }^{8}$ NOAA Earth System Research Laboratory, Boulder, Colorado, USA.

Copyright 2009 by the American Geophysical Union. 0148-0227/09/2008JD010126\$09.00
}

[Intergovernmental Panel on Climate Change, 2007] and surface air pollution [Economic Commission for Europe, 2007]. A number of studies have used $d \mathrm{O}_{3} / d \mathrm{CO}$ concentration enhancement ratios in continental outflow, where $\mathrm{CO}$ is a long-lived tracer of combustion, to estimate continental anthropogenic influences to ozone on the global scale [Mauzerall et al., 1998; Pochanart et al., 1999; Zhang et al., 2006] including from North America [Chin et al., 1994; Parrish et al., 1993, 1998]. We use here observations from the International Consortium for Atmospheric Research on Transport and Transformation (ICARTT) aircraft campaign over eastern North America in summer 2004 [Singh et al., 2006; Fehsenfeld et al., 2006], interpreted with a global 3-D model of tropospheric chemistry (GEOS-Chem) to improve and update estimates of North American influence on global tropospheric ozone including both anthropogenic and natural sources. Stationary $\mathrm{NO}_{\mathrm{x}}$ and mobile $\mathrm{CO}$ sources in the United States have been decreasing rapidly over the past decade [Frost et al., 2006; Kim et al., 2006; Parrish, 2006; Hudman et al., 2007, 2008]. The ICARTT campaign provides constraints on these decreases as well as on natural sources of ozone precursors from lightning and fires.

[3] CO, a product of incomplete combustion, has a mean atmospheric lifetime of 2 months against oxidation by the hydroxyl radical $(\mathrm{OH})$, its main atmospheric sink. It is a tracer for continental outflow, and the ozone-CO relationship is a marker for ozone production in a polluted air mass. 
Previous observations in U.S. boundary layer air and North American outflow in summer have shown consistently strong correlations with enhancement ratios $d \mathrm{O}_{3} / d \mathrm{CO}=$ 0.3-0.4 mol mol ${ }^{-1}$ [Chin et al., 1994; Mao and Talbot, 2004; Parrish et al., 1993, 1998]. Although CO per se is not a limiting precursor for ozone production, combined information on $d \mathrm{O}_{3} / d \mathrm{CO}$ and $\mathrm{CO}$ emissions enables estimate of anthropogenic ozone export [Parrish et al., 1993; Chin et al., 1994]. Here, we examine recent changes in this relationship due to recent emission reductions.

[4] Hudman et al. [2007, 2008] previously applied GEOS-Chem to the ICARTT data to derive constraints on U.S. emissions of $\mathrm{CO}$ and $\mathrm{NO}_{\mathrm{x}}$ from combustion and lightning. They found that the ICARTT data implied a $50 \%$ reduction in anthropogenic $\mathrm{NO}_{\mathrm{x}}$ emissions from stationary sources (power plant and industry) relative to the National Emission Inventory of the U.S. Environmental Protection Agency (EPA), constructed for 1999 (NEI 99), consistent with 1999-2004 regulations of stationary $\mathrm{NO}_{\mathrm{x}}$ sources. Additionally, the ICARTT data implied a summertime U.S. anthropogenic CO source $60 \%$ lower than specified in the NEI 99 inventory and weaker than the biogenic $\mathrm{CO}$ source from the oxidation of VOCs. A larger lightning source than expected from models was found in the upper troposphere over the eastern United States [Martin et al., 2006; Hudman et al., 2007]. This is consistent with recent studies suggesting higher $\mathrm{NO}_{\mathrm{x}}$ yields per flash from lightning at northern midlatitudes than in the tropics [Huntrieser et al., 2008; Ott et al., 2007].

[5] The summer of 2004 was one of the strongest fire seasons on record for Alaska and western Canada [Turquety et al., 2007]. Elevated levels of $\mathrm{CO}$ and ozone associated with these fires were observed as far as the central Atlantic [Cook et al., 2007; Val Martín et al., 2006] and western Europe [Real et al., 2007]. Here, we examine the quantitative impacts of the fires on the hemispheric-scale ozone budget.

\section{ICARTT}

[6] ICARTT was a coordinated multiaircraft and groundbased atmospheric chemistry field program over eastern North America and the North Atlantic in July-August 2004. Two important components were the NOAA Intercontinental Transport and Chemical Transformation (ITCT $2 \mathrm{k} 4$ ) and the NASA Intercontinental Transport Experiment-North America, Phase A (INTEX-A) campaigns. The ITCT2k4 campaign [Fehsenfeld et al., 2006] took place 3 July to 15 August over the NW Atlantic and the NE United States out of Portsmouth, New Hampshire. It used a WP-3D aircraft (ceiling $6 \mathrm{~km}$ ). The INTEX-A campaign [Singh et al., 2006] took place 29 June to 14 August over the central and eastern United States, and the North Atlantic, from bases at Edwards Air Force Base (California), St. Louis (Missouri), and Portsmouth (New Hampshire). It used a DC-8 aircraft (ceiling $12 \mathrm{~km}$ ).

[7] We use here the measurements of $\mathrm{CO}$, ozone, $\mathrm{NO}_{2}$, and NO taken aboard both aircraft (the DC- 8 NO data are those from Pennsylvania State University [Ren et al., 2008]). Intercomparisons between the two aircraft showed agreement to within the combined accuracy of the measurements for $\mathrm{CO}$, ozone, and $\mathrm{NO}_{2}$ ( $\mathrm{NO}$ data were not com- pared) (G. Chen, NASA Langley, personal communication, 2006, http://www-air.larc.nasa.gov/missions/intexna/meascomparison.htm). We use the ITCT2k4 and INTEX-A measurements as a single data set in our analysis. We also make use of other data sets collected on the aircraft including peroxyacetylnitrate (PAN), nitric acid $\left(\mathrm{HNO}_{3}\right)$, hydrogen cyanide $(\mathrm{HCN})$, and acetonitrile $\left(\mathrm{CH}_{3} \mathrm{CN}\right)$. Details on the aircraft data are given by Fehsenfeld et al. [2006] and Singh et al. [2006].

[8] Surface measurements were taken during ITCT2k4 from Chebogue Point on the southern tip of Nova Scotia $\left(44^{\circ} \mathrm{N}, 66^{\circ} \mathrm{W}\right)$ to observe outflow from the northeastern United States [Fehsenfeld et al., 2006]. Millet et al. [2006b] found that $\mathrm{CO}$, ozone, and aerosol mass concentrations were elevated respectively by $30 \%, 56 \%$, and more than $300 \%$ at Chebogue Point during U.S. outflow periods. Here we use the $\mathrm{CO}$ and ozone data averaged over 30 -min intervals.

\section{Model Description}

[9] We simulate the ICARTT observations with the GEOS-Chem global 3-D model of tropospheric chemistry (version 7.02; http://www.as.harvard.edu/chemistry/trop/ geos/) driven by assimilated meteorological observations from the Goddard Earth Observing System (GEOS-4) of the NASA Global Modeling and Assimilation Office (GMAO). The model is applied to a global simulation of ozone$\mathrm{NO}_{\mathrm{x}}$-VOC-aerosol chemistry. A general description of GEOS-Chem is given by Bey et al. [2001] and a specific description of the coupled oxidant-aerosol simulation as used here is given by Hudman et al. [2007]. The horizontal resolution of the model is $2^{\circ} \times 2.5^{\circ}$. There are 30 vertical layers including 12 below $10 \mathrm{~km}$ and 5 below $2 \mathrm{~km}$. The simulation was conducted for 15 months starting from chemical climatology; the 13-month spin-up time effectively removes the influence of initial conditions.

[10] For comparison with observations, the model is sampled along the aircraft flight tracks for the flight times. Fine-scale fresh pollution and biomass burning plumes must be excluded from this comparison because of intrinsically large model errors associated with plume displacement and dilution over a $2^{\circ} \times 2.5^{\circ}$ grid box. We diagnose fresh pollution plumes in the observations by $\mathrm{NO}_{\mathrm{x}} / \mathrm{NO}_{\mathrm{y}}>0.4 \mathrm{~mol}$ $\mathrm{mol}^{-1}$ (here, $\mathrm{NO}_{\mathrm{y}}=\mathrm{NO}_{\mathrm{x}}+\mathrm{PAN}+\mathrm{HNO}_{3}$ ). When $\mathrm{NO}_{\mathrm{y}}$ is not available we diagnose fresh pollution plumes by $\mathrm{NO}_{2}>$ 4 ppbv. We also remove fresh biomass burning plumes as diagnosed by $\mathrm{HCN}>500$ pptv or $\mathrm{CH}_{3} \mathrm{CN}>225$ pptv [ de Gouw et al., 2006]. When filtered, all species over that time period are removed. Several of the WP-3D flights were targeted at urban and power plant plume characterization [Fehsenfeld et al., 2006] and we further exclude those data. Overall these filters exclude $7 \%$ and $21 \%$ of the DC- 8 and WP-3D data, respectively.

[11] Global anthropogenic emissions in the model are as described by Park et al. [2004]. Emissions for the contiguous United States are summarized in Table 1. Anthropogenic emissions are from NEI 99 with modifications described by Hudman et al. [2007, 2008], including a generalized $50 \%$ decrease in $\mathrm{NO}_{\mathrm{x}}$ emissions from power plants and industry reflecting 1999-2004 reductions [Frost et al., 2006], and a 60\% decrease in CO emissions reflecting both a decreasing trend and a likely overestimate in the 
Table 1. $\mathrm{CO}$ and $\mathrm{NO}_{\mathrm{x}}$ Sources in the Contiguous United States for 1 July to 15 August 2004

\begin{tabular}{|c|c|c|}
\hline Source Type & $\mathrm{CO}(\mathrm{Tg})$ & $\mathrm{NO}_{\mathrm{x}}{ }^{\mathrm{a}}(\mathrm{g} \mathrm{N})$ \\
\hline Fuel and industry & $6.4^{\mathrm{b}}$ & $0.62^{\mathrm{c}}$ \\
\hline Vegetation & $9.1^{\mathrm{d}}$ & - \\
\hline Soil & - & $0.12^{\mathrm{e}}$ \\
\hline Biomass Burning ${ }^{f}$ & 0.16 & 0.003 \\
\hline Aircraft & - & 0.021 \\
\hline Lightning ${ }^{\mathrm{g}}$ & - & 0.27 \\
\hline Total & 15.7 & 1.03 \\
\hline
\end{tabular}

${ }^{\mathrm{a}} \mathrm{NO}_{\mathrm{x}}$ emissions are as in the work by Hudman et al. [2007].

${ }^{\mathrm{b}}$ Including a secondary source of $1.8 \mathrm{Tg}$ from oxidation of anthropogenic VOCs, calculated for the purposes of this table by assuming VOC-specific CO yields from Duncan et al. [2007]. The anthropogenic emission of CO (4.6 $\mathrm{Tg} \mathrm{CO}$ ) represents a $60 \%$ reduction from the NEI 99 inventory to match the ICARTT observations [Hudman et al., 2008].

${ }^{\mathrm{c}}$ Including $0.28 \mathrm{Tg} \mathrm{N}$ from transport, $0.17 \mathrm{Tg} \mathrm{N}$ from power generation and industry reflecting a 50\% reduction from the NEI 99 inventory to match the ICARTT observations [Hudman et al., 2007], and $0.17 \mathrm{Tg} \mathrm{N}$ from other sources.

${ }^{\mathrm{d}}$ Including $6.7 \mathrm{Tg}$ from isoprene oxidation and $2.4 \mathrm{Tg}$ from oxidation of other biogenic VOCs (acetone, monoterpenes, = C3 alkenes). For the purposes of this table, we assume a 2.3 molar yield of HCHO from isoprene oxidation as constrained by the ICARTT observations [Millet et al., 2006a] and further assume $100 \%$ conversion of $\mathrm{HCHO}$ to $\mathrm{CO}$. For the other biogenic VOCs we use the CO yields from Duncan et al. [2007].

e Including $0.03 \mathrm{Tg}$ from fertilizer application.

${ }^{\mathrm{f}}$ North American fires during ICARTT were mainly outside the contiguous United States; Alaskan and Canadian fires produced $19 \mathrm{Tg}$ $\mathrm{CO}$ and $0.10 \mathrm{Tg} \mathrm{N}$ during this period.

${ }^{\mathrm{g}}$ Contiguous United States and coastal waters $\left(130^{\circ}-70^{\circ} \mathrm{W}, 25^{\circ}-50^{\circ} \mathrm{N}\right)$.

original NEI 99 inventory [Hudman et al., 2008]. Biogenic emissions of isoprene and monoterpenes are from the GEIA inventory [Guenther et al., 1995]. Monoterpenes are accounted as sources of $\mathrm{CO}$ with an instantaneous yield of $0.2 \mathrm{CO}$ per atom C [Duncan et al., 2007]. Biogenic alkene $(\mathrm{C} \geq 3)$ emissions are assumed to be $10 \%$ of isoprene on a per molecule basis. Biogenic acetone emissions are as in the work by Jacob et al. [2002].

[12] We increase the U.S. lightning $\mathrm{NO}_{\mathrm{x}}$ source by a factor of four relative to the standard GEOS-Chem scheme (i.e., to $500 \mathrm{~mol} / \mathrm{flash}$ ) to match constraints from the upper tropospheric $\mathrm{NO}_{\mathrm{x}}$ aircraft data and lightning observations from the National Lightning Detection Network (NLDN) [Hudman et al., 2007].

[13] Boreal fire emissions for $\mathrm{CO}$ are from the ICARTT daily inventory of Turquety et al. [2007], resulting in $19 \mathrm{Tg}$ $\mathrm{CO}$ for the 1 July to 15 August period. There have been very few measurements of emission factors for $\mathrm{NO}_{\mathrm{x}}$ from boreal fires. On the basis of a summary of available observations, Lapina et al. [2008] estimate molar $\mathrm{NO}_{\mathrm{x}} / \mathrm{CO}$ emission ratios of $3 \times 10^{-3} \mathrm{~mol} / \mathrm{mol}$ for smoldering and $28 \times 10^{-3} \mathrm{~mol} / \mathrm{mol}$ for flaming combustion. Following Kasischke and Bruhwiler [2003], Turquety et al. [2007] assume $50 \%$ flaming and $50 \%$ smoldering combustion, except for peat (assumed to be $100 \%$ smoldering), which results in an overall mean $\mathrm{NO}_{\mathrm{x}} / \mathrm{CO}$ emission ratio of 0.011 , which we use here. Fire emissions during ICARTT were frequently lofted to the free troposphere [de Gouw et al., 2006]. While injection heights are uncertain, we assume following Turquety et al. [2007] that $40 \%$ of fire emissions were released at the surface and $60 \%$ in the free troposphere with uniform vertical distribution by mass.
[14] The boundary ventilation rate in the model has been validated through the successful simulation of the observed shapes of the mean vertical profiles for propane [Hudman et al., 2008], acetylene [Xiao et al., 2007], and formaldehyde [Millet et al., 2006a]. Additionally, $\mathrm{NO}_{\mathrm{x}}$ emissions vented to the free troposphere as $\mathrm{NO}_{\mathrm{y}}$ (observed $=16 \pm 10 \%$, modeled $=14 \pm 9 \%$ ) and its partitioning is well captured [Hudman et al., 2007]. Because of its short lifetime in the boundary layer $(<1$ day), surface NOx concentrations are primarily governed by local emissions and chemical loss [Li et al., 2004, Table 3]. After applying the 1.7 correction factor to DC- $8 \mathrm{OH}$ measurements (as discussed by Ren et al. [2008]), the $\mathrm{OH}$ comparison is unbiased [Hudman et al., 2007], suggesting the $\mathrm{NO}_{\mathrm{x}}$ lifetime in the model is well represented.

\section{Effect of U.S. NO $\mathrm{N}_{\mathrm{x}}$ Emission Reductions on Surface Ozone}

[15] Figure 1 shows observed and simulated afternoon ozone concentrations at $0-1.5 \mathrm{~km}$ altitude averaged over the GEOS-Chem grid boxes. For comparison with observations, the model was sampled along the aircraft flight tracks for the flight times and then averaged. Cool temperatures, cloudiness, and frequent frontal passages made summer 2004 a mild ozone season over the eastern United States [Gilliland et al., 2008]. Mean observed concentrations were typically 45-60 ppbv. High values observed offshore reflect aged urban pollution plumes deliberately sampled by the WP-3D aircraft in stratified air [Neuman et al., 2006] and should not be viewed as representative mean of the grid box. The simulation using NEI 99 is too high over the United States by $5-15 \mathrm{ppbv}\left(\mathrm{R}^{2}=0.38\right)$.

[16] Frost et al. [2006] determined from stack sampling that power plant emissions of $\mathrm{NO}_{\mathrm{x}}$ decreased by $50 \%$ between 1999 and 2003, resulting in an 11\% reduction in total anthropogenic $\mathrm{NO}_{\mathrm{x}}$ emissions during the summer ozone season. Previously, Hudman et al. [2007] showed that ICARTT $\mathrm{NO}_{\mathrm{x}}$ observations imply a $22 \%$ reduction in anthropogenic $\mathrm{NO}_{\mathrm{x}}$ emissions relative to NEI 99. This $\mathrm{NO}_{\mathrm{x}}$ reduction improves the ozone simulation in the south and Midwest, as shown in Figure 1, though it only slightly improves the overall model-to-observed ozone correlation $\left(\mathrm{R}^{2}=0.41\right)$.

[17] The $\mathrm{NO}_{\mathrm{x}}$ emission reductions (Figure 2) are largest in the Midwest, reflecting the distribution of power plants. The largest resulting ozone decreases in the model (up to 8 ppbv) are in the southeast (Figure 2); the Midwest shows weaker decreases (4-6 ppbv). Kim et al. [2006] examined the effect of power plant $\mathrm{NO}_{\mathrm{x}}$ emission reductions, following Frost et al. [2006], on simulated ozone levels by using the WRF-Chem regional model at $27 \times 27 \mathrm{~km}^{2}$ resolution applied for summer 2004. They found a similar spatial distribution of ozone changes, with local concentrations decreasing by as much as $7 \mathrm{ppbv}$ and greater ozone reductions per unit $\mathrm{NO}_{\mathrm{x}}$ in the south.

[18] The spatial variability in ozone response to $\mathrm{NO}_{\mathrm{x}}$ emission reductions can be explained by variability in the ozone production efficiency (OPE), defined as the number of ozone molecules produced $(P)$ per molecule of $\mathrm{NO}_{\mathrm{x}}$ oxidized $(L), P_{3} / L \mathrm{NO}_{\mathrm{x}}$ [Liu et al., 1987]. OPE decreases with increasing $\mathrm{NO}_{\mathrm{x}}$ and increases with increasing isoprene and UV flux [Liu et al., 1987; Hirsch et al., 1996], and is 
(a)

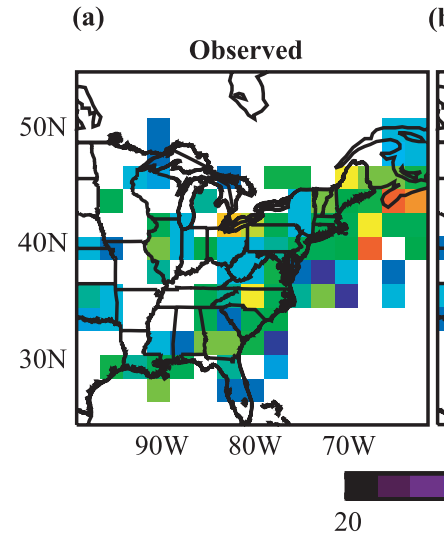

(b)
Simulated (NEI 99 emissions) (c) Simulated (NEI 99

stationary NO reduced by $50 \%$ )

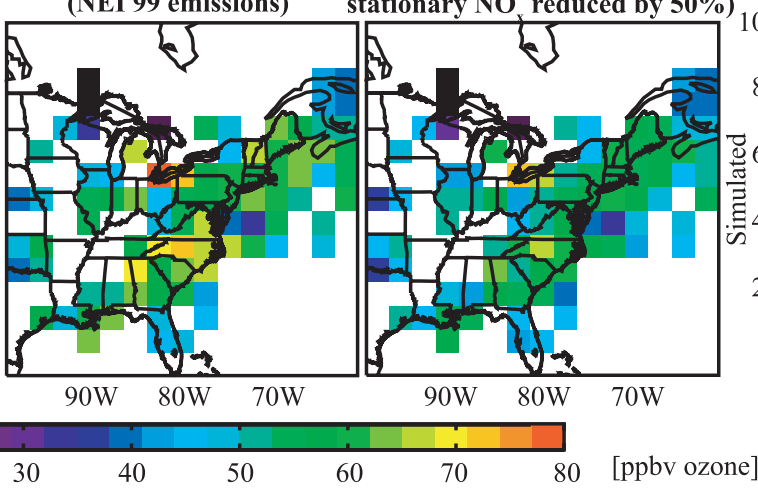

(d)

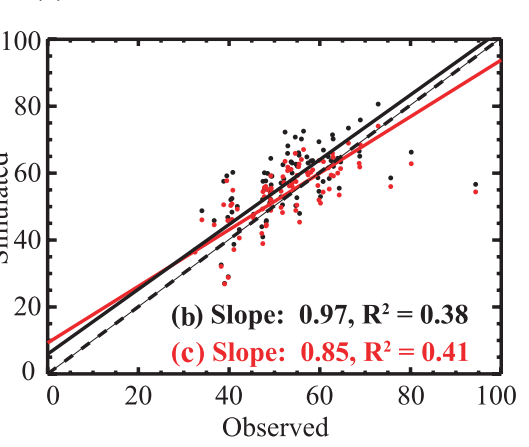

Figure 1. Mean afternoon (1100-1700 LT) ozone concentrations at $0-1.5 \mathrm{~km}$ altitude during ICARTT. (a) Observations are compared to (b) the model simulation with NEI 99 emissions and (c) the simulation with $\mathrm{NO}_{\mathrm{x}}$ stationary sources decreased by $50 \%$. (d)A scatterplot of this gridded comparison and $\mathrm{y}=\mathrm{x}$ line (dashed).

thus higher in the southeast than in the northeast. We find in the GEOS-Chem simulation that the Midwest boundary layer has OPE values in the range 2.5-3.5, whereas the southeast has values in the range $4-5.5$, consistent with the simulated pattern of ozone decreases.

\section{Ozone-CO Relationship in the Boundary Layer}

[19] Figure 3 shows simulated versus observed ozone-CO correlations for the boundary layer aircraft flight tracks $(0-$ $1.5 \mathrm{~km}$ altitude) in the afternoon (1100-1700 LT), for photochemically aged air as diagnosed by $\mathrm{NO}_{x} / \mathrm{NO}_{y}<0.3$ mol mol ${ }^{-1}$ following Chin et al. [1994]. Also shown are correlations at Chebogue Point for the W-SE wind sector which sampled North American outflow [Millet et al., 2006b]. Model results are from the standard simulation including reduced $\mathrm{NO}_{\mathrm{x}}$ and $\mathrm{CO}$ emissions relative to NEI 99 (Table 1). The $d \mathrm{O}_{3} / d \mathrm{CO}$ enhancement ratio (as defined by the slope of the reduced-major-axis regression line, allowing for errors on both variables and 95\% confidence intervals, determined by nonparametric bootstrap resampling) is $0.46 \pm 0.02 \mathrm{~mol} \mathrm{~mol}^{-1}\left(\mathrm{R}^{2}=0.56\right)$ in the aircraft observations and $0.36 \pm 0.02 \mathrm{~mol} \mathrm{~mol}^{-1}\left(\mathrm{R}^{2}=0.23\right)$ in the model sampled along the aircraft flight tracks. The discrepancy is caused principally by a population of model points in the southeast with relatively high ozone $(40-60 \mathrm{ppb})$ and low $\mathrm{CO}$, reflecting an ozone overestimate in inflow from the Gulf of Mexico as previously discussed by Fiore et al. [2002]. The observed $d \mathrm{O}_{3} / d \mathrm{CO}$ enhancement ratio at Chebogue Point is $0.41 \pm 0.03\left(\mathrm{R}^{2}=0.47\right)$, consistent though slightly lower than the aircraft data, likely due to surface deposition. The full ensemble of Chebogue Point data (all
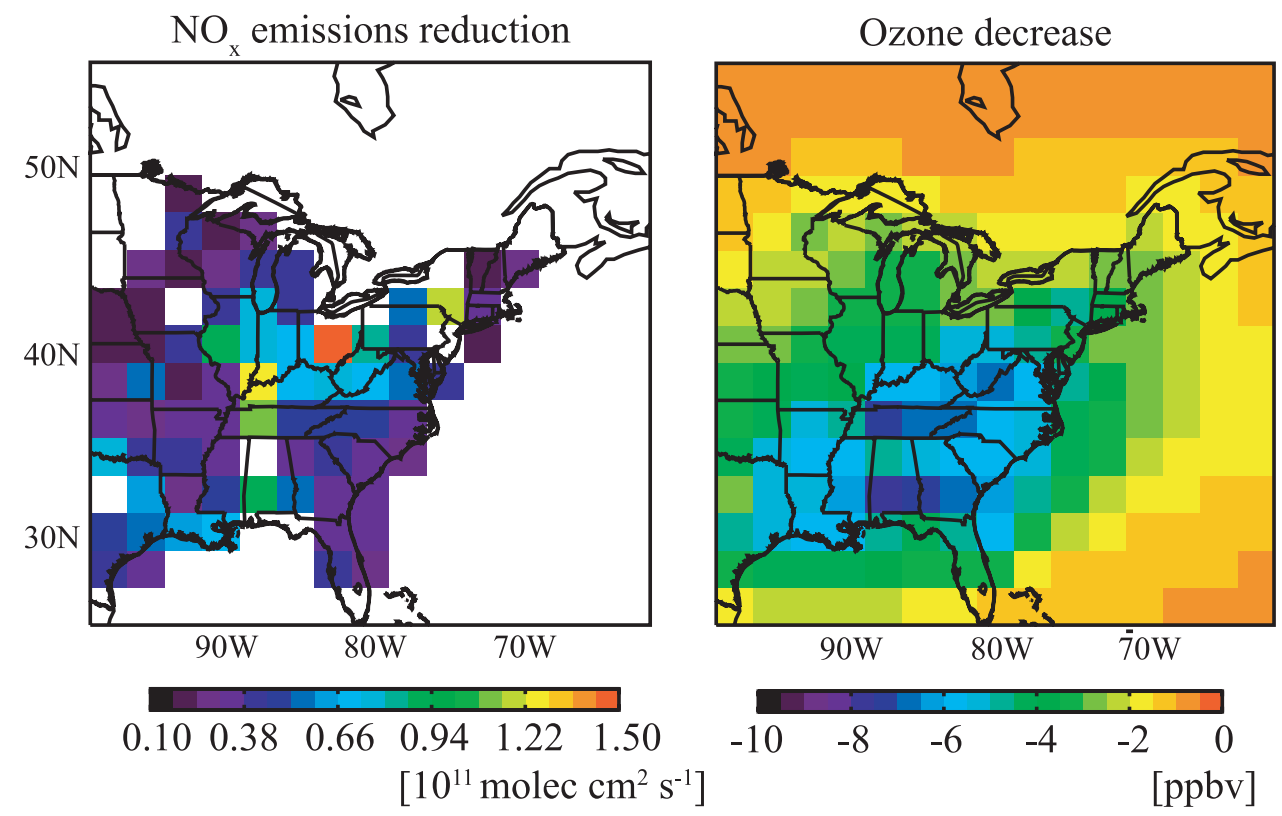

Figure 2. (left) U.S. $\mathrm{NO}_{\mathrm{x}}$ emission reductions from 1999 to 2004 due to $50 \%$ reduction in stationary $\mathrm{NO}_{\mathrm{x}}$ sources and (right) resulting decrease of mean afternoon ozone concentrations at $0-1.5 \mathrm{~km}$ altitude (1100-1700 LT) simulated for the ICARTT period. 

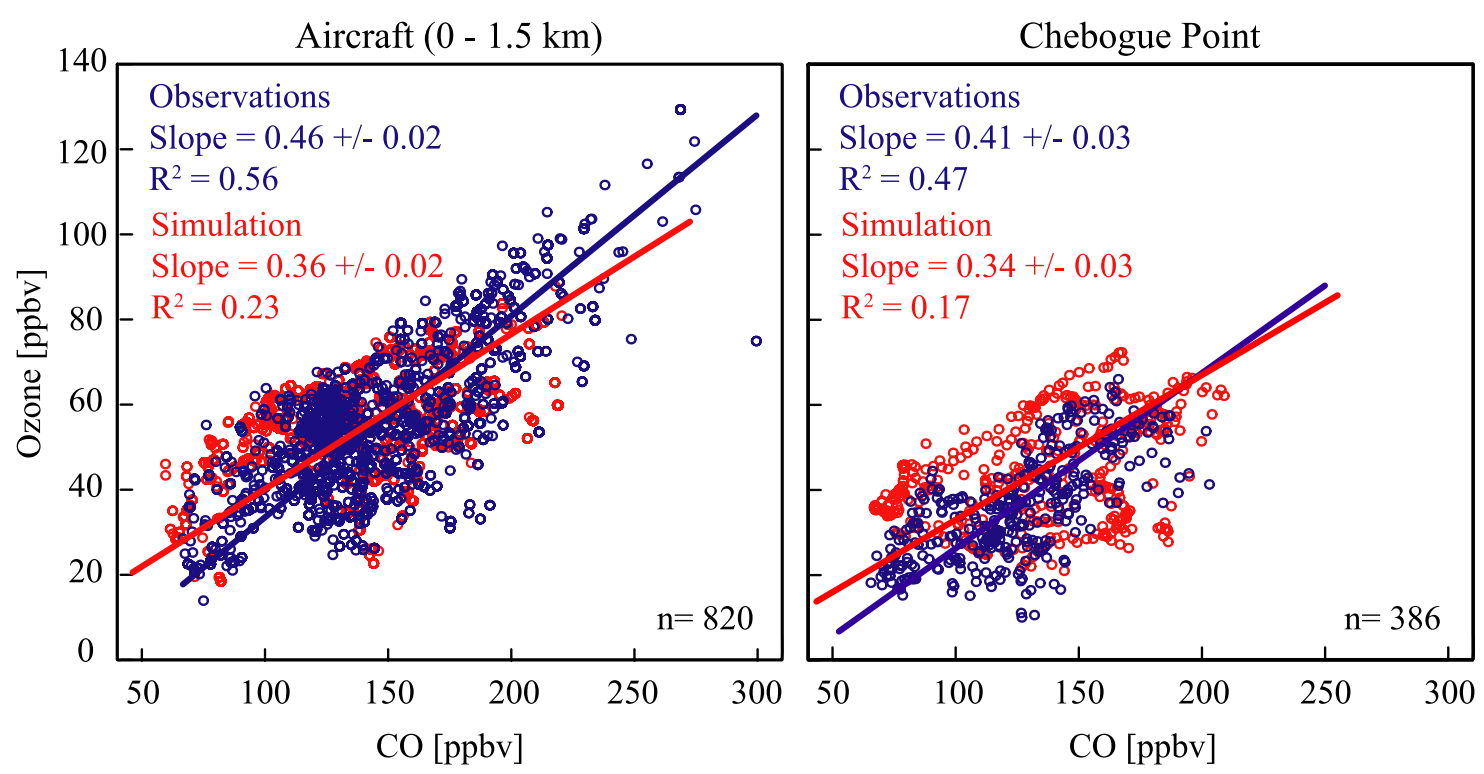

Figure 3. Ozone-CO correlations in the boundary layer during ICARTT: (left) aircraft flight tracks and (right) Chebogue Point. Observations (blue) are compared to model results (red). Flight tracks are for the afternoon (1100-1700 LT) in the boundary layer and east of $100^{\circ} \mathrm{W}$. Chebogue Point data are for the subset with observed winds from SE-W $\left(120^{\circ}-270^{\circ} \mathrm{W}\right)$. Slopes are from a reduced-major-axis regression.

wind sectors) has $d \mathrm{O}_{3} / d \mathrm{CO}=0.47 \pm 0.03$, but the $\mathrm{R}^{2}$ degrades to 0.26 . The model is somewhat too low with $d \mathrm{O}_{3} / d \mathrm{CO}$ of $0.34 \pm 0.03\left(\mathrm{R}^{2}=0.17\right)$, and this again appears to be due to an excessive ozone background.

[20] Previous observations of the summertime $d \mathrm{O}_{3} / d \mathrm{CO}$ enhancement ratios in the United States had consistently found values of 0.3-0.4. Chin et al. [1994] report enhancement ratios at three eastern U.S. sites of $0.28-0.32\left(\mathrm{R}^{2}=\right.$ 0.43-0.78) for 1988-1992. Parrish et al. [1998] report ratios at four sites in Atlantic Canada of $0.28-0.40\left(\mathrm{R}^{2}=\right.$ $0.48-0.68)$ for $1991-1994$. The abnormally cool summer in 2004 suppressed ozone production, suggesting observed changes in $\mathrm{dO}_{3} / \mathrm{dCO}$ would be a lower bound. The higher values seen during ICARTT could reflect decadal changes in U.S. CO and $\mathrm{NO}_{\mathrm{x}}$ emissions. Mao and Talbot [2004], however, found a slightly lower $d \mathrm{O}_{3} / d \mathrm{CO}$ of $0.37\left(\mathrm{R}^{2}=\right.$ 0.77 ) over New Hampshire during southwesterly flow for the summers 2001-2003.

[21] The $d \mathrm{O}_{3} / d \mathrm{CO}$ enhancement ratio in North American outflow can be interpreted as the number of ozone molecules produced per molecule of $\mathrm{CO}$ emitted. If we assume that $\mathrm{NO}_{\mathrm{x}}$ is in steady state between emission and loss $\left(E_{\mathrm{NOx}}=L_{\mathrm{NOx}}\right)$, we can further interpret the $d \mathrm{O}_{3} / d \mathrm{CO}$ enhancement ratio as the product of the OPE $\left(P_{\mathrm{O} 3} / L_{\mathrm{NOx}}\right)$ and the molar $\mathrm{NO}_{\mathrm{x}} / \mathrm{CO}$ source ratio $\left(E_{N / C}=E_{N O x} / E_{C O}\right)$, the former taken from the model and the latter constrained by ICARTT observations [Hudman et al., 2007, 2008]:

$$
\frac{d O_{3}}{d C O} \approx O P E \times E_{N / C}
$$

Consider the evolution of $\mathrm{E}_{\mathrm{N} / \mathrm{C}}$ over the northeast United States (EPA regions 1-3, http://www.epa.gov/epahome/ locate2.htm) for the period 1994-2004. The 1 July to 15 August 2004 anthropogenic emissions for the northeast were $1.2 \mathrm{Tg} \mathrm{CO}$ and $0.10 \mathrm{Tg} \mathrm{N}$, to which we must add $0.87 \mathrm{Tg}$ CO from biogenic emissions. Parrish [2006] estimates urban anthropogenic $\mathrm{CO}$ emissions decreased by $4.6 \% \mathrm{a}^{-1}$ during the period 1987-2002. Assuming that this trend continued through 2004 and that the CO source from NMVOC oxidation (mainly biogenic) remained constant, we estimate a total CO source decrease of $23 \%$ over 1994 2004. $\mathrm{NO}_{\mathrm{x}}$ emissions from powerplants remained roughly constant until 2000, at which time reductions in power sources began to be phased in, resulting in a $50 \%$ decrease by summer 2004 [Frost et al., 2006]. Hudman et al. [2007] found that to match ICARTT $\mathrm{NO}_{\mathrm{x}}$ observations, large industry must similarly be reduced by $50 \%$, resulting in a $22 \%$ decrease in $\mathrm{NO}_{\mathrm{x}}$ emissions nationwide and a $15 \%$ decrease in the northeast. The decadal change in the mobile source of $\mathrm{NO}_{\mathrm{x}}$ is uncertain (estimates range from slight decreases to slight increases) and thus we assume constant mobile emissions over the period [Parrish, 2006; Martin et al., 2006; Hudman et al., 2007; Gilliland et al., 2008].

[22] We thus estimate a $10 \%$ increase in the molar $\mathrm{NO}_{\mathrm{x}} /$ CO source ratio $E_{N / C}$ over 1994-2004. We further find in the model that the $\mathrm{NO}_{\mathrm{x}}$ emission reduction relative to the NEI 99 inventory caused a mean increase in the OPE over the northeast of $9 \%$. The product of the trends in the $\mathrm{NO}_{\mathrm{x}} /$ $\mathrm{CO}$ source ratio and in the OPE would thus be expected to yield a $19 \%$ increase in the $d \mathrm{O}_{3} / d \mathrm{CO}$ enhancement ratio, consistent with the trend in the observed ratio as described above.

\section{Hemispheric Ozone Enhancements From North American Anthropogenic, Biomass Burning, and Lightning Emissions}

[23] The ICARTT observations provided strong constraints on North American sources of $\mathrm{NO}_{\mathrm{x}}$ from anthropo- 
Table 2. North American Enhancements to the Summertime Northern Hemisphere Burden of Tropospheric Ozone $^{\mathrm{a}}$

\begin{tabular}{lccc}
\hline North American Source & $\begin{array}{c}\mathrm{NO}_{\mathrm{x}} \\
\text { Emission }^{\mathrm{b}}(\mathrm{Tg} \mathrm{N})\end{array}$ & $\begin{array}{c}\text { Ozone } \\
\text { Production Efficiency }\end{array}$ & $\begin{array}{c}\text { Hemispheric Ozone } \\
\text { Enhancement }^{\mathrm{c}}(\mathrm{Tg}, \%)\end{array}$ \\
\hline Lightning & 0.28 & 32 & $9.0(5.1 \%)$ \\
Biomass burning & 0.11 & 18 & $2.0(1.1 \%)$ \\
Fossil fuel & 0.72 & 15 & $10.9(6.2 \%)$ \\
Total & 1.11 & 20 & $21.9(12.4 \%)$ \\
\hline
\end{tabular}

${ }^{\mathrm{a}}$ Obtained by difference between the standard simulation and a sensitivity simulation with the corresponding source shut off, and with sufficient (11 months) initialization in each case. Here and elsewhere, North America is defined as Canada and the continental United States. Values are for the 1 July to 15 August 2004 ICARTT period.

${ }^{\mathrm{b}}$ For the 1 July to 15 August 2004 period.

${ }^{\mathrm{c}}$ Total Northern Hemisphere ozone burden is $175.4 \mathrm{Tg}$ in the standard GEOS-Chem simulation.

genic emissions, lightning, and biomass burning, and implied large corrections to prior emission estimates (Table 1 and Hudman et al. [2007]). Table 2 gives the $\mathrm{NO}_{\mathrm{x}}$ emission totals from each source for North America, defined here as the U.S. and Canada. We use here this information to quantify the North American contribution to tropospheric ozone on the hemispheric scale by conducting sensitivity simulations with anthropogenic, biomass burning, or lightning emissions over North America shut off. The associated ozone enhancement is diagnosed by difference with results from the standard simulation. We do not examine the sensitivity to the soil source as it is small compared to the anthropogenic source (Table 1). Each simulation is initialized with an 11-month spin-up.

[24] Figure 4 compares simulated and observed mean vertical distributions of ozone for the ensemble of DC8 flights along with the simulated anthropogenic, biomass burning, and lightning enhancements. The total North American enhancement amounts to about $30 \mathrm{ppbv}$ in the boundary layer and $20 \mathrm{ppbv}$ in the free troposphere. The boundary layer enhancement is mainly anthropogenic, but the free troposphere has equal enhancements from anthropogenic and lightning $\mathrm{NO}_{\mathrm{x}}$. Biomass burning adds $1 \mathrm{ppbv}$ from the surface to $4 \mathrm{~km}$ and less above.

[25] Figure 5 shows the ozone enhancements from the different North American $\mathrm{NO}_{\mathrm{x}}$ sources on the scale of the Northern Hemisphere at different altitudes, and Table 2 summarizes the corresponding hemispheric budgets. Li et al. [2005] found that a semipermanent upper level anticyclone above the southern United States in summer allows ozone buildup in the upper troposphere by trapping convectively lifted precursors and lightning $\mathrm{NO}_{\mathrm{x}}$. Cooper et al. [2006] confirmed the resulting ozone maximum by analysis of ozonesonde data during ICARTT, and found an associated 11-14 ppbv contribution to ozone from lightning. We find a similar $10-17 \mathrm{ppbv}$ enhancement in the upper troposphere over the Gulf Coast and see it stretching downwind across the subtropical Atlantic to Europe. North American lightning contributes 5.1\% of the total Northern Hemisphere ozone burden for the ICARTT period, comparable to the North American anthropogenic ozone burden (Table 2). Even though the North American lightning $\mathrm{NO}_{\mathrm{x}}$ source is less than half of the fossil fuel source, its OPE is much higher (Table 2) [also see Wu et al., 2007].

[26] The mean simulated North American anthropogenic ozone enhancement is highest in the eastern United States in surface air but shifts northeast to the North Atlantic in the free troposphere, reflecting the ventilation of the U.S. boundary layer by frontal passages [Fuelberg et al., 2007]. In the upper troposphere, the anthropogenic enhancement extends to higher latitudes than that from lightning. We find that North American anthropogenic emissions enhance the tropospheric ozone burden in the Northern Hemisphere by $6.1 \%$ (Table 2). Enhancements in surface air over western Europe are 3-6 ppbv, consistent with previous estimates by Li et al. [2002].

[27] Biomass burning ozone enhancements are highest in boreal North America, reflecting the distribution of fires in the summer 2004, and extend to the Arctic, where they are comparable to fossil fuel influence in the lower and middle troposphere, though not in the upper troposphere. North American biomass burning emissions during the summer 2004 enhanced hemispheric ozone burden by 1\% (2 Tg).

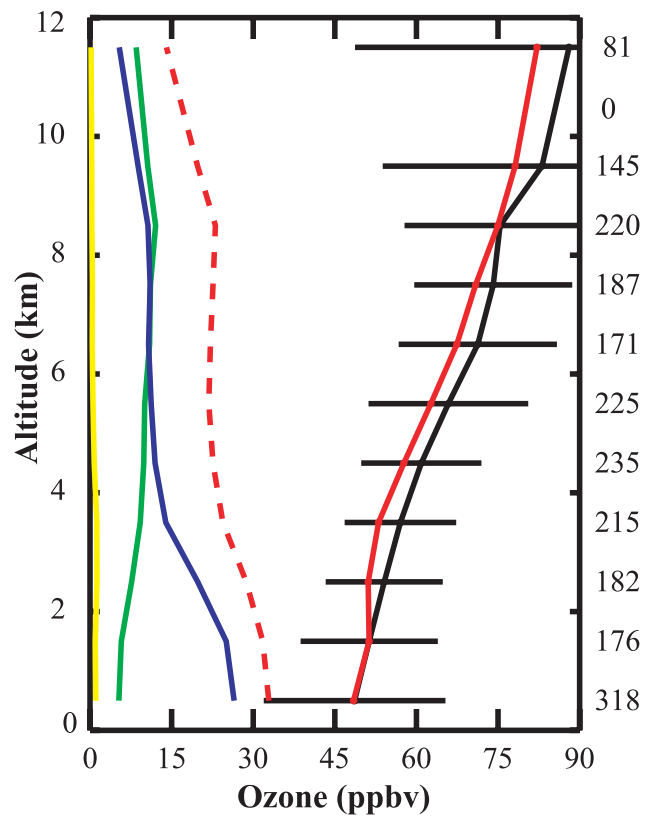

Figure 4. Mean vertical profiles of ozone over eastern North America during ICARTT. Observations from the DC8 aircraft (black) are compared to model results sampled along the aircraft flight tracks (red). Model enhancements from North American biomass burning (yellow), lightning (green), anthropogenic emissions (blue) and all three sources combined (dashed red) are shown. Horizontal bars are standard deviations on the observations. Number of gridded observations per $1-\mathrm{km}$ bin is shown. 

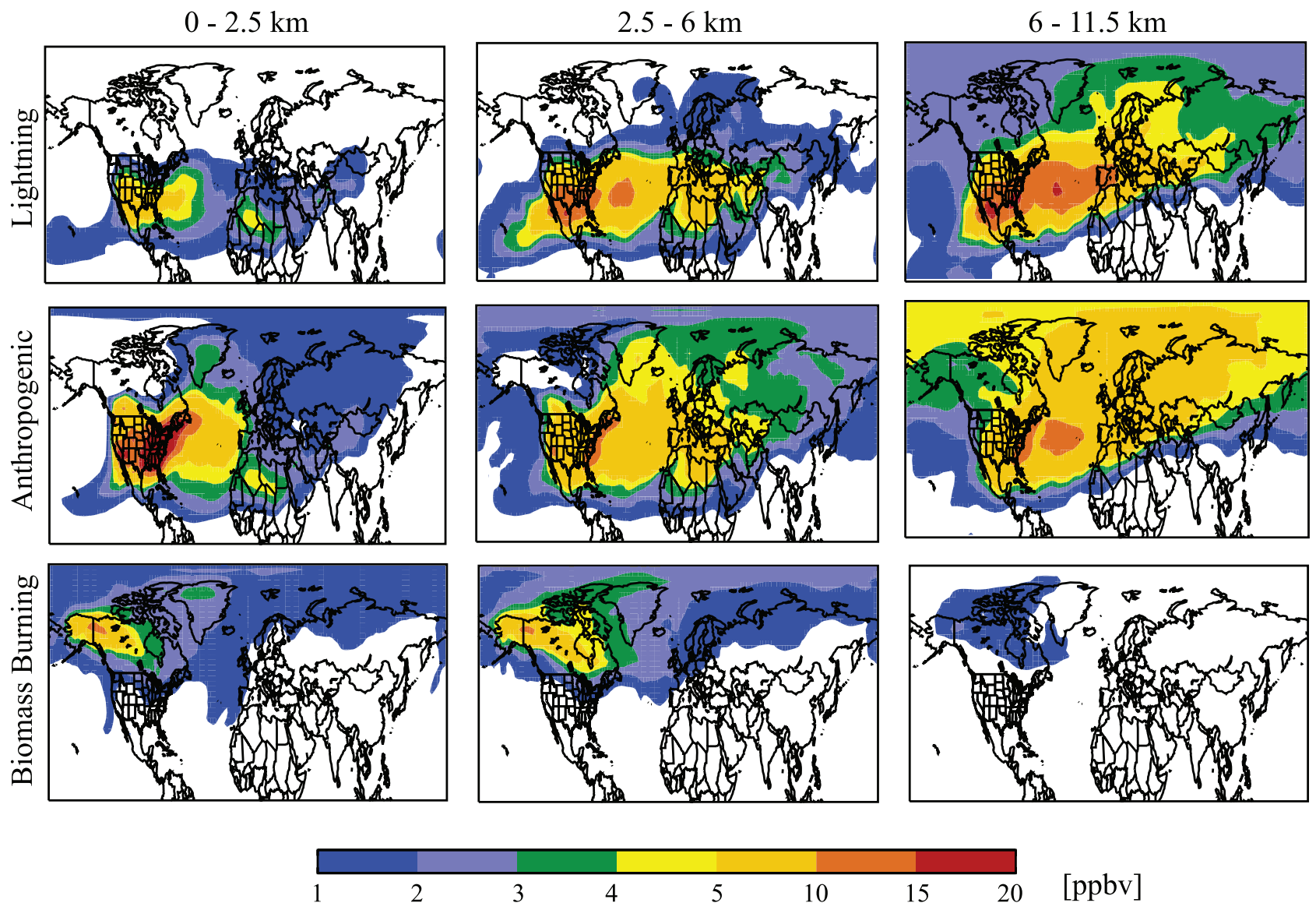

Figure 5. Simulated ozone enhancements from North American lightning, anthropogenic, and biomass burning emissions at $0-2.5,2.5-6$, and $6-11.5 \mathrm{~km}$ altitude as diagnosed by sensitivity simulation with individual sources turned off as described in section 6. Values are means for 1 July to 15 August 2004.

Observations of fire plumes at the PICO-NARE station, in the central Atlantic, showed mean $d \mathrm{O}_{3} / d \mathrm{CO}$ in aged fire plumes of $0.2 \mathrm{~mol} \mathrm{~mol}^{-1}$ [Val Martín et al., 2006], which if applied to the $19 \mathrm{Tg} \mathrm{CO}$ inventory used here would correspond to a $3 \%(6 \mathrm{Tg})$ ozone enhancement. Such an enhancement is consistent with a modeling study by Pfister et al. [2006] which used a molar $\mathrm{NO}_{\mathrm{x}} / \mathrm{CO}$ emission ratio of $0.27,2.5 \mathrm{x}$ higher than used here. Using molar $\mathrm{NO}_{\mathrm{x}} / \mathrm{CO}$ emission ratios from 0.007 to 0.32 , Cook et al. [2007] found corresponding increases in hemispheric ozone burdens during ICARTT of $1-3 \%(2-6 \mathrm{Tg})$. As discussed in Section 3 , observational estimates of $\mathrm{NO}_{\mathrm{x}} / \mathrm{CO}$ emission ratios are closer to the lower end of this range. It thus appears that boreal fire emissions have a negligible influence on summertime ozone concentrations on the hemispheric scale.

\section{Conclusions}

[28] The ICARTT study in summer 2004 provided extensive observations of ozone, $\mathrm{CO}$, and $\mathrm{NO}_{\mathrm{y}}$ species over the eastern United States and western North Atlantic, from the surface to $12 \mathrm{~km}$ altitude. These data offer new information to better constrain and understand North American influence on tropospheric ozone over the scale of the Northern Hemisphere. Hudman et al. [2007] used the ICARTT observations of $\mathrm{NO}_{\mathrm{y}}$ species from two aircraft (NASA DC-8 and NOAA WP-3D), together with simulations with the GEOS-Chem chemical transport model (CTM), to improve estimates of U.S. fossil fuel and lightning $\mathrm{NO}_{\mathrm{x}}$ sources. Here we used the ICARTT data together with GEOS-Chem to examine the effect of recent $\mathrm{NO}_{\mathrm{x}}$ emission reductions [Frost et al., 2006; Hudman et al., 2007] on surface ozone in the United States, to quantify and interpret ozone-CO correlations seen in pollution outflow, and to assess the implications for the effect of natural and anthropogenic North American emissions on Northern Hemispheric ozone.

[29] Hudman et al. [2007] found that the ICARTT boundary layer $\mathrm{NO}_{\mathrm{x}}$ data are consistent with a 50\% summertime decrease in power plant and industry $\mathrm{NO}_{\mathrm{x}}$ emissions in the eastern United States between 1999 and 2004 [Frost et al., 2006] yielding a 22\% decrease in the overall anthropogenic $\mathrm{NO}_{\mathrm{x}}$ source in that season. Applying this decrease in the GEOS-Chem model reduces simulated ozone concentrations by $6-8 \mathrm{ppbv}$ in the southeast and 4-6 ppbv in the Midwest, improving the comparison to observations. Even though the $\mathrm{NO}_{\mathrm{x}}$ emission reduction is largest in the Midwest, the ozone decrease is greater in the southeast due to higher ozone production efficiency per unit $\mathrm{NO}_{\mathrm{x}}(\mathrm{OPE})$.

[30] Aircraft data during ICARTT show a consistent $d \mathrm{O}_{3} / d \mathrm{CO}$ enhancement ratio of $0.46 \mathrm{~mol} \mathrm{~mol}^{-1}$ over the eastern United States and in U.S. outflow. Previous studies 
using data from the early 1990s had found a consistent summertime enhancement ratio of $0.3-0.4$, lower than in ICARTT. We show that this increase can be explained by a combination of OPE increase $(9 \%)$ due to decreasing $\mathrm{NO}_{\mathrm{x}}$ emissions and increase in the $\mathrm{NO}_{\mathrm{x}} / \mathrm{CO}$ source ratio $(10 \%)$ due to even more rapid decrease of $\mathrm{CO}$ emissions.

[31] The ICARTT data offer a unique ensemble of constraints on $\mathrm{NO}_{\mathrm{x}}$ emissions from fossil fuel combustion, lightning, and biomass burning in North America during summer 2004. We used the $\mathrm{NO}_{\mathrm{x}}$ emissions derived from these constraints to better quantify North American influence from these different sources on tropospheric ozone over the scale of the Northern Hemisphere. We find that North American $\mathrm{NO}_{\mathrm{x}}$ emissions in summer 2004 increased the hemispheric tropospheric ozone burden by $12 \%$, with comparable contributions from fossil fuel and lightning (5$6 \%$ ), but only $1 \%$ from biomass burning.

[32] Acknowledgments. This work was funded by the NASA Global Tropospheric Chemistry Program and by the NOAA Office of Global Programs. Aboard the NOAA WP-3D aircraft measurements were provided for ozone, $\mathrm{NO}, \mathrm{NO}_{2}$ (Tom Ryerson, NOAA ESRL), acetonitrile (Joost De Gouw, CIRES/NOAA ESRL), $\mathrm{HNO}_{3}$ (Andy Neuman, NOAA CIRES/ ESRL), and PAN (Frank Flocke and Aaron Swanson, NCAR) and aboard the NASA DC-8 aircraft for HCN and PAN (Hanwant Singh, NASA Ames), $\mathrm{NO}_{2}$ (Ron Cohen and Tim Bertram, University of California, Berkeley), and NO (Bill Brune and Xinrong Ren).

\section{References}

Bey, I., D. J. Jacob, R. M. Yantosca, J. A. Logan, B. D. Field, A. M. Fiore, Q. B. Li, H. G. Y. Liu, L. J. Mickley, and M. G. Schultz (2001), Global modeling of tropospheric chemistry with assimilated meteorology: Model description and evaluation, J. Geophys. Res., 106, 23,073-23,095, doi:10.1029/2001JD000807.

Chin, M., D. J. Jacob, J. W. Munger, D. D. Parrish, and B. G. Doddridge (1994), Relationship of Ozone and Carbon-Monoxide over North-America, J. Geophys. Res., 99, 14,565-14,573, doi:10.1029/94JD00907.

Cook, P. A., et al. (2007), Forest fire plumes over the North Atlantic: P-TOMCAT model simulations with aircraft and satellite measurements from the ITOP/ICARTT campaign, J. Geophys. Res., 112, D10S43, doi:10.1029/2006JD007563.

Cooper, O. R., et al. (2006), Large upper tropospheric ozone enhancements above midlatitude North America during summer: In situ evidence from the IONS and MOZAIC ozone measurement network, J. Geophys. Res., 111, D24S05, doi:10.1029/2006JD007306.

de Gouw, J. A., et al. (2006), Volatile organic compounds composition of merged and aged forest fire plumes from Alaska and western Canada, J. Geophys. Res., 111, D10303, doi:10.1029/2005JD006175.

Duncan, B. N., J. A. Logan, I. Bey, I. A. Megretskaia, R. M. Yantosca, P. C. Novelli, N. B. Jones, and C. P. Rinsland (2007), The global budget of CO, 1988-1997: Source estimates and validation with a global model, J. Geophys. Res., 112, D22301, doi:10.1029/2007JD008459.

Economic Commission for Europe (2007), Hemispheric transport of air pollution 2007: Interim report/prepared by the Task Force on Hemispheric Transport of Air Pollution acting within the framework of the Convention on Long-range Transboundary Air Pollution, United Nations, Geneva.

Fehsenfeld, F. C., et al. (2006), International Consortium for Atmospheric Research on Transport and Transformation (ICARTT): North America to Europe-Overview of the 2004 summer field study, J. Geophys. Res., 111, D23S01, doi:10.1029/2006JD007829.

Fiore, A. M., D. J. Jacob, I. Bey, R. M. Yantosca, B. D. Field, A. C. Fusco, and J. G. Wilkinson (2002), Background ozone over the United States in summer: Origin, trend, and contribution to pollution episodes, J. Geophys. Res., 107(D15), 4275, doi:10.1029/2001JD000982.

Frost, G. J., et al. (2006), Effects of changing power plant $\mathrm{NO}_{\mathrm{x}}$ emissions on ozone in the eastern United States: Proof of concept, J. Geophys. Res., 111, D12306, doi:10.1029/2005JD006354.

Fuelberg, H. E., M. J. Porter, C. M. Kiley, J. J. Halland, and D. Morse (2007), Meteorological conditions and anomalies during the Intercontinental Chemical Transport Experiment-North America, J. Geophys. Res., 112, D12S06, doi:10.1029/2006JD007734.

Gilliland, A. B., C. Hogrefe, R. W. Pinder, J. M. Godowitch, K. L. Foley, and S. T. Rao (2008), Dynamic evaluation of regional air quality models:
Assessing changes in $\mathrm{O}_{3}$ stemming from changes in emissions and meteorology, Atmos. Environ., 42(20), 5110-5123, doi:10.1016/j.atmosenv. 2008.02.018.

Guenther, A., et al. (1995), A global model of natural volatile organic compound emissions, J. Geophys. Res., 100, 8873-8892, doi:10.1029/ 94JD02950.

Hirsch, A. I., J. W. Munger, D. J. Jacob, L. W. Horowitz, and A. H. Goldstein (1996), Seasonal variation of the ozone production efficiency per unit $\mathrm{NO}_{\mathrm{x}}$ at Harvard Forest, Massachusetts, J. Geophys. Res., 101, 12,659-12,666, doi:10.1029/96JD00557.

Hudman, R. C., et al. (2007), Surface and lightning sources of nitrogen oxides over the United States: Magnitudes, chemical evolution, and outflow, J. Geophys. Res., 112, D12S05, doi:10.1029/2006JD007912.

Hudman, R. C., L. T. Murray, D. J. Jacob, D. B. Millet, S. Turquety, S. Wu, D. R. Blake, A. H. Goldstein, J. Holloway, and G. W. Sachse (2008), Biogenic versus anthropogenic sources of $\mathrm{CO}$ in the United States, Geophys. Res. Lett., 35, L04801, doi:10.1029/2007GL032393.

Huntrieser, H., U. Schumann, H. Schlager, H. Höller, A. Giez, H.-D. Betz, D. Brunner, C. Forster, O. Pinto Jr., and R. Calheiros (2008), Lightning activity in Brazilian thunderstorms during TROCCINOX: Implications for $\mathrm{NO}_{\mathrm{x}}$ production, Atmos. Chem. Phys., 8, 21-953.

Intergovernmental Panel on Climate Change (2007), Climate Change 2007: The Physical Science Basis. Contribution of Working Group I to the Fourth Assessment Report of the Intergovernmental Panel on Climate Change, edited by S. Solomon et al., Cambridge Univ. Press, Cambridge, U.K.

Jacob, D. J., B. D. Field, E. M. Jin, I. Bey, Q. Li, J. A. Logan, R. M. Yantosca, and H. B. Singh (2002), Atmospheric budget of acetone, J. Geophys. Res., 107(D10), 4100, doi:10.1029/2001JD000694.

Kasischke, E. S., and L. M. Bruhwiler (2003), Emissions of carbon dioxide, carbon monoxide and methane from boreal forest fires in 1998, J. Geophys. Res., 107, 8146, doi:10.1029/2001JD000461. [printed 108(D1), 2003]

Kim, S.-W., A. Heckel, S. A. McKeen, G. J. Frost, E.-Y. Hsie, M. K. Trainer, A. Richter, J. P. Burrows, S. E. Peckham, and G. A. Grell (2006), Satellite-observed U. S. power plant $\mathrm{NO}_{\mathrm{x}}$ emission reductions and their impact on air quality, Geophys. Res. Lett., 33, L22812, doi:10.1029/2006GL027749.

Lapina, K., R. E. Honrath, R. C. Owen, M. Val Martín, E. J. Hyer, and P. Fialho (2008), Late summer changes in burning conditions in the boreal regions and their implications for $\mathrm{NO}_{\mathrm{x}}$ and $\mathrm{CO}$ emissions from boreal fires, J. Geophys. Res., 113, D11304, doi:10.1029/ 2007JD009421.

Li, Q., et al. (2002), Transatlantic transport of pollution and its effects on surface ozone in Europe and North America, J. Geophys. Res., 107(D13), 4166, doi:10.1029/2001JD001422.

Li, Q., D. J. Jacob, J. W. Munger, R. M. Yantosca, and D. D. Parrish (2004), Export of NOy from the North American boundary layer: Reconciling aircraft observations and global model budgets, J. Geophys. Res., 109, D02313, doi:10.1029/2003JD004086.

Li, Q., D. J. Jacob, R. Park, Y. Wang, C. L. Heald, R. Hudman, R. M. Yantosca, R. V. Martin, and M. Evans (2005), North American pollution outflow and the trapping of convectively lifted pollution by upper-level anticyclone, J. Geophys. Res., 110, D10301, doi:10.1029/2004JD005039.

Liu, S. C., M. Trainer, F. C. Fehsenfeld, D. D. Parrish, E. J. Williams, D. W. Fahey, G. Gubler, and P. C. Murphy (1987), Ozone production in the rural troposphere and the Implications for regional and global ozone distributions, J. Geophys. Res., 92, 4191-4207, doi:10.1029/ JD092iD04p04191.

Mao, H., and R. Talbot (2004), $\mathrm{O}_{3}$ and $\mathrm{CO}$ in New England: Temporal variations and relationships, J. Geophys. Res., 109, D21304, doi:10.1029/ 2004JD004913.

Marenco, A., H. Gouget, P. Nédélec, J.-P. Pagés, and F. Karcher (1994), Evidence of a long-term increase in tropospheric ozone from Pic du Midi data series: Consequences: Positive radiative forcing, J. Geophys. Res., 99, 16,617-16,632, doi:10.1029/94JD00021.

Martin, R. V., C. E. Sioris, K. Chance, T. B. Ryerson, T. H. Bertram, P. J. Wooldridge, R. C. Cohen, J. A. Neuman, A. Swanson, and F. M. Flocke (2006), Evaluation of space-based constraints on global nitrogen oxide emissions with regional aircraft measurements over and downwind of eastern North America, J. Geophys. Res., 111, D15308, doi:10.1029/ 2005JD006680.

Mauzerall, D. L., J. A. Logan, D. J. Jacob, B. E. Anderson, D. R. Blake, J. D. Bradshaw, B. Heikes, G. W. Sachse, H. Singh, and B. Talbot (1998), Photochemistry in biomass burning plumes and implications for tropospheric ozone over the tropical South Atlantic, J. Geophys. Res., 103, 8401-8424, doi:10.1029/97JD02612.

Millet, D. B., et al. (2006a), Formaldehyde distribution over North America: Implications for satellite retrievals of formaldehyde columns and 
isoprene emission, J. Geophys. Res., 111, D24S02, doi:10.1029/ 2005JD006853

Millet, D. B., et al. (2006b), Chemical characteristics of North American surface layer outflow: Insights from Chebogue Point, Nova Scotia, J. Geophys. Res., 111, D23S53, doi:10.1029/2006JD007287.

Neuman, J. A., et al. (2006), Reactive nitrogen transport and photochemistry in urban plumes over the North Atlantic Ocean, J. Geophys. Res. 111, D23S54, doi:10.1029/2005JD007010.

Ott, L. E., K. E. Pickering, G. L. Stenchikov, H. Huntrieser, and U. Schumann (2007), Effects of lightning $\mathrm{NO}_{\mathrm{x}}$ production during the 21 July European Lightning Nitrogen Oxides Project storm studied with a three-dimensional cloud-scale chemical transport model, J. Geophys. Res., 112, D05307, doi:10.1029/2006JD007365.

Park, R. J., D. J. Jacob, B. D. Field, R. M. Yantosca, and M. Chin (2004), Natural and transboundary pollution influences on sulfate-nitrate-ammonium aerosols in the United States: Implications for policy, J. Geophys. Res., 109, D15204, doi:10.1029/2003JD004473.

Parrish, D. D. (2006), Critical evaluation of US on-road vehicle emission inventories, Atmos. Environ., 40, 2288-2300, doi:10.1016/j.atmosenv. 2005.11.033.

Parrish, D. D., et al. (1993), Export of North America ozone pollution to the North Atlantic Ocean, Science, 259, 1436-1439, doi:10.1126/ science.259.5100.1436.

Parrish, D. D., M. Trainer, J. S. Holloway, J. E. Yee, M. S. Warshawsky, F. C. Fehsenfeld, G. L. Forbes, and J. L. Moody (1998), Relationships between ozone and carbon monoxide at surface sites in the North Atlantic region, J. Geophys. Res., 103, 13,357-13,376, doi:10.1029/98JD00376.

Pfister, G. G., et al. (2006), Ozone production from the 2004 North American boreal fires, J. Geophys. Res., 111, D24S07, doi:10.1029/ 2006JD007695.

Pochanart, P., J. Hirokawa, Y. Kajii, H. Akimoto, and M. Nakao (1999), Influence of regional-scale anthropogenic activity in northeast Asia on seasonal variations of surface ozone and carbon monoxide observed at Oki, Japan, J. Geophys. Res., 104, 3621-3632, doi:10.1029/ 1998JD100071.

Real, E., et al. (2007), Processes influencing ozone levels in Alaskan forest fire plumes during long-range transport over the North Atlantic, J. Geophys. Res., 112, D10S41, doi:10.1029/2006JD007576.

Ren, X., et al. (2008), $\mathrm{HO}_{\mathrm{x}}$ chemistry during INTEX-A 2004: Observation, model calculation, and comparison with previous studies, J. Geophys. Res., 113, D05310, doi:10.1029/2007JD009166.

Singh, H. B., W. H. Brune, J. H. Crawford, D. J. Jacob, and P. B. Russell (2006), Overview of the summer 2004 Intercontinental Chemical Trans- port Experiment-North America (INTEX-A), J. Geophys. Res., 111, D24S01, doi:10.1029/2006JD007905.

Turquety, S., et al. (2007), Inventory of boreal fire emissions for North America in 2004: The importance of peat burning and pyroconvective injection, J. Geophys. Res., 112, D12S03, doi:10.1029/2006JD007281.

Val Martín, M., R. E. Honrath, R. C. Owen, G. Pfister, P. Fialho, and F. Barata (2006), Significant enhancements of nitrogen oxides, black carbon, and ozone in the North Atlantic lower free troposphere resulting from North American boreal wildfires, J. Geophys. Res., 111, D23S60, doi:10.1029/2006JD007530.

Wang, Y., and D. J. Jacob (1998), Anthropogenic forcing on tropospheric ozone and $\mathrm{OH}$ since preindustrial times, J. Geophys. Res., 103, 31,12331,136, doi:10.1029/1998JD100004.

Wu, S., L. J. Mickley, D. J. Jacob, J. A. Logan, R. M. Yantosca, and D. Rind (2007), Why are there large differences between models in global budgets of tropospheric ozone?, J. Geophys. Res., 112, D05302, doi:10.1029/2006JD007801.

Xiao, Y., D. J. Jacob, and S. Turquety (2007), Atmospheric acetylene and its relationship with $\mathrm{CO}$ as an indicator of air mass age, J. Geophys. Res., 112, D12305, doi:10.1029/2006JD008268

Zhang, L., et al. (2006), Ozone-CO correlations determined by the TES satellite instrument in continental outflow regions, Geophys. Res. Lett. 33, L18804, doi:10.1029/2006GL026399.

M. Avery, Atmospheric Sciences Division, NASA Langley Research Center, Mail Stop 483, 21 Langley Boulevard, Hampton, VA 23681-2199, USA.

A. H. Goldstein, Department of Environmental Science, Policy, and Management, University of California, 151 Hilgard Hall, Berkeley, CA 94720-3110, USA.

J. Holloway, NOAA Earth System Research Laboratory, 325 Broadway Street, Boulder, CO 80305, USA.

R. C. Hudman, Department of Chemistry, University of California Berkeley, CA 94720-1460, USA. (hudman@berkeley.edu)

D. J. Jacob, L. T. Murray, and S. Wu, School of Engineering and Applied Sciences, Pierce Hall, 29 Oxford Street, Harvard University, Cambridge, MA 02138, USA.

D. B. Millet, Department of Soil, Water and Climate, University of Minnesota-Twin Cities, 1991 Upper Buford Circle, St. Paul, MN 55108 , USA.

S. Turquety, Service d'Aéronomie, Institut Pierre-Simon Laplace, 4 Place Jussieu, F-75005 Paris, France. 